\title{
Teaching Video NeuroImages: Jaw Clonus in Amyotrophic Lateral Sclerosis
}

\author{
Abeer Goel, MD, Ritu Shree, MD, DM, Heena Kathuria, MD, Sahil Mehta, Vivek Lal, and \\ Karthik Vinay Mahesh, MD, DM
}

Neurology ${ }^{\circledR}$ 2021;96:e2563. doi:10.1212/WNL.0000000000011127

We present a case of amyotrophic lateral sclerosis (ALS) in a middle-aged woman who presented with a 2-year history of dysarthria and dysphagia. On examination, she had spastic dysarthria, jaw clonus (video 1), hyperreflexia, and fasciculations involving the tongue, trunk, and extremities. Jaw clonus is an upper motor sign that localizes to the dysfunction of corticobulbar fibers cranial to the 5th nerve nucleus. It is analogous to ankle and patellar clonus in lower limbs. Although jaw clonus is highly suggestive of ALS, it has also rarely been described in patients with multiple cerebral infarcts and CNS demyelinating disorder. Jaw clonus or accentuated jaw jerk serves as a useful clinical sign to distinguish ALS from cervical myelopathy. ${ }^{1,2}$

\section{Study Funding}

No targeted funding reported.

\section{Disclosure}

The authors report no disclosures relevant to the manuscript. Go to Neurology.org/ $\mathrm{N}$ for full disclosures.

\section{Appendix Authors}

\begin{tabular}{lll}
\hline Author & Location & Contribution \\
\hline Abeer Goel, MD & $\begin{array}{l}\text { Department of Neurology, Postgraduate Institute of Medical } \\
\text { Education and research (PGIMER), Chandigarh, India }\end{array}$ & $\begin{array}{c}\text { Involved in patient care } \\
\text { and management }\end{array}$ \\
\hline $\begin{array}{l}\text { Ritu Shree, MD, } \\
\text { DM }\end{array}$ & $\begin{array}{l}\text { Department of Neurology, Postgraduate Institute of Medical } \\
\text { Education and research (PGIMER), Chandigarh, India }\end{array}$ & Collection of data \\
\hline $\begin{array}{l}\text { Heena Kathuria, } \\
\text { MD }\end{array}$ & $\begin{array}{l}\text { Department of Neurology, Postgraduate Institute of Medical } \\
\text { Education and research (PGIMER), Chandigarh, India }\end{array}$ & Video making and editing \\
\hline $\begin{array}{l}\text { Sahil Mehta } \\
\text { Department of Neurology, Postgraduate Institute of Medical }\end{array}$ & $\begin{array}{l}\text { Conceptualization of the } \\
\text { paper }\end{array}$ \\
\hline $\begin{array}{l}\text { Vivek Lal } \\
\text { Karthik Vinay } \\
\text { Mahesh, MD, DM }\end{array}$ & $\begin{array}{l}\text { Department of Neurology, Postgraduate Institute of Medical } \\
\text { Education and research (PGIMER), Chandigarh, India }\end{array}$ & $\begin{array}{l}\text { Final revision and edition } \\
\text { of paper }\end{array}$ \\
\hline
\end{tabular}

\section{References}

1. Beevor CE, De Watteville A. A case of amyotrophic lateral sclerosis with clonus of the lower jaw. Brain 1886;8:516-519.

2. Saifee TA, Macerollo A. Jaw clonus in motor neuron disease: an interesting case and review of literature. Neurol Sci 2018;39:949-950.

\section{Correspondence}

Dr. Mahesh

skarthikvm@gmail.com

\section{MORE ONLINE}

○ Video

$\rightarrow$ Teaching slides

lww.com/WNL/B265 


\section{Neurology}

\section{Teaching Video NeuroImages: Jaw Clonus in Amyotrophic Lateral Sclerosis \\ Abeer Goel, Ritu Shree, Heena Kathuria, et al.}

Neurology 2021;96;e2563 Published Online before print October 27, 2020

DOI 10.1212/WNL.0000000000011127

This information is current as of October 27, 2020

\section{Updated Information \& Services}

References

Subspecialty Collections

Permissions \& Licensing

Reprints including high resolution figures, can be found at: http://n.neurology.org/content/96/20/e2563.full

This article cites 2 articles, 0 of which you can access for free at: http://n.neurology.org/content/96/20/e2563.full\#ref-list-1

This article, along with others on similar topics, appears in the following collection(s):

All Movement Disorders

http://n.neurology.org/cgi/collection/all_movement_disorders Amyotrophic lateral sclerosis

http://n.neurology.org/cgi/collection/amyotrophic_lateral_sclerosis_ Anterior nerve cell disease

http://n.neurology.org/cgi/collection/anterior_nerve_cell_disease

Clinical neurology examination

http://n.neurology.org/cgi/collection/clinical_neurology_examination

Motor cortex

http://n.neurology.org/cgi/collection/motor_cortex

Information about reproducing this article in parts (figures,tables) or in its entirety can be found online at:

http://www.neurology.org/about/about_the_journal\#permissions

Information about ordering reprints can be found online:

http://n.neurology.org/subscribers/advertise

Neurology ${ }^{\circledR}$ is the official journal of the American Academy of Neurology. Published continuously since 1951, it is now a weekly with 48 issues per year. Copyright @ 2020 American Academy of Neurology. All rights reserved. Print ISSN: 0028-3878. Online ISSN: 1526-632X.

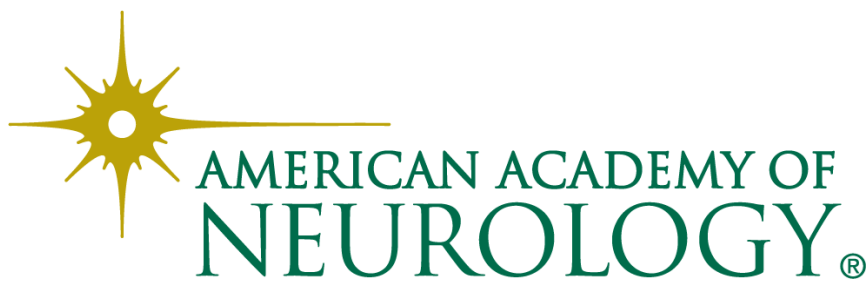

